\title{
Transnational land investment in Costa Rica: tracing residential tourism and its implications for development ${ }^{1}$
}

\author{
Dr. Femke van Noorloos
}

International Development Studies, Dept. Human Geography \& Planning, Faculty of Geosciences, Utrecht University, The Netherlands, $\underline{\text { H.J.vanNoorloos@uu.nl }}$

This is an Accepted Manuscript of a book chapter published by Zed Books in 2014, M. Kaag \& A. Zoomers (Eds.), The global land grab: beyond the hype, available online: https://www.zedbooks.net/shop/book/the-global-land-grab/

(C) 2017. This manuscript version is made available under the CC-BY-NC-ND 4.0 license http://creativecommons.org/licenses/by-nc-nd/4.0/

\section{Introduction}

The current global land rush is not a new phenomenon: land grabs, the dispossession of rural communities, and deepening commercialisation in rural areas have existed since colonial times. The novelty of current developments lies in the speed of change, the large scale of the phenomenon worldwide, and the expectation that it will continue for a long time (Anseeuw et al. 2012; Cotula 2012). Nevertheless, given the current hype on large-scale land acquisitions, it is interesting to trace recent developments to earlier processes of land-based change and make comparisons. In this article I focus on the northwest coast of Costa Rica (the province of Guanacaste), an area where real estate development and tourism have created many land pressures in recent years. However, the area has been subject to land grabs ever since colonisation and particularly since the late nineteenth century, when a small number of foreign and domestic investors were able to acquire huge amounts of land in Guanacaste, mainly for the cattle sector (Edelman 1998). The aim is thus to give a more dynamic view of 'land grab' processes by tracing current processes to historical developments and by showing the long-term effects of a land grab that took place long ago.

The global trend for large-scale land acquisitions causes much concern. According to many studies, its implications have been mostly negative: increased preoccupation with food

\footnotetext{
${ }^{1}$ The data and analysis presented in this chapter are presented in a much more extensive version in Van Noorloos (2012).
} 
security and rural people's livelihoods; the displacement, enclosure and exclusion of local populations; conflict; and pressure on resources (German, Schoneveld and Mwangi 2011; Oxfam 2011; Anseeuw et al. 2012; Global Witness 2012). In Latin America, the expulsion of people from their lands is lesser in scale than in other regions; however, changes in land property relations should be seen in a broader perspective, as there has been a process of increased land re-concentration and inequalities in access to land, as well as 'deagrarianisation' (Borras et al. 2012; Peluso and Lund 2011).

The debate on large-scale land acquisitions and commercial pressures on land has mostly focused on two types of land acquisition, namely purchases directed to food supply (food crops, agribusiness, pasture land) and biofuel crops. However important the issue of land acquisition for food and biofuel crops may be, we need to view new commercial pressures on land in its entire width (Zoomers 2010). Particularly in Latin America, land acquisitions outside the realm of food and fuel have been important (Borras et al. 2012). For instance, large land acquisitions are taking place in the context of climate change mitigation and adaptation. For example, forest plantations can be related to REDD (Reducing Emissions from Deforestation and Forest Degradation) policies; mining concessions cause pressures on land; and the establishment of large-scale tourism complexes and residential tourism resorts also adds to these pressures (Zoomers 2010). Speculation in itself (land and houses as a safe haven for investment) is also a driver of large-scale land acquisitions (Anseeuw et al. 2012).

Tourism has only recently received more attention in the land grab debate, and researchers seem to differ on whether to include tourism-related land acquisitions. I argue that tourism resources (landscape, view, land, water) are among the key resources for capitalist development and drive current land acquisitions. Residential tourism in particular is based on land and speculation. Residential tourism has recently become more prominent in developing countries: it is the temporary or permanent mobility of relatively well-to-do citizens from mostly Western countries to a variety of tourist destinations, where they buy (or sometimes rent) property (Aledo 2008; Benson and O'Reilly 2009; McWatters 2009). ${ }^{2}$ Most residential tourists are Europeans or North Americans who migrate to the South in search of a more relaxed lifestyle, a lower cost of living, better weather, etc. Both the number of residential tourists and the size of the related land investments have increased markedly during the past ten years in various countries in Latin America, Africa, and Asia. Residential tourism is thus a

\footnotetext{
${ }^{2}$ The phenomenon has also been termed lifestyle mobilities, lifestyle migration, amenity migration, international retirement migration, and second home development in the literature (see, among others, Williams and Hall 2000; MPI 2006; Gustafson 2008; Benson and O’Reilly 2009; Janoschka 2009; McIntyre 2009; Hoogendoorn and Visser 2010). By using the concept 'residential tourism', I locate my research in the debates on the implications of this phenomenon in local destinations, especially because I focus on a region in the global South.
} 
relatively new type of commercial pressure on land, a pressure which is expected to increase in many developing countries in the future - for example, in Costa Rica, Nicaragua, Panama, Ecuador, Chile, Uruguay, Argentina, Brazil, South Africa, Mozambique, Thailand, and Turkey.

Residential tourism is generating increased pressures on land and resources. It is triggering a process of foreignisation of land, since land has become an important object of investment for many external actors. This naturally takes place on a smaller scale and in a more concentrated manner than in the case of agricultural investment; however, the scale of the capital involved is large (see Borras et al. 2012). As most of the land investment takes place on privately owned land and not in outright illegal ways, the term 'land grab' is not fitting; nevertheless, increased land acquisition and control by external actors does take place.

In this chapter I aim to provide a better understanding of residential tourism and its implications for equitable and sustainable development in Costa Rica, and I trace these developments to historical processes of land grab, thereby contributing to the debate on the dynamics and long-term effects of large-scale land acquisitions.

This chapter is based on research in one of the main and (until recently) fastest growing residential tourism destinations in Latin America: the northwest coastal region of Costa Rica, Guanacaste Province (Figure 5.1). This area has been connected to the North American economy since the late nineteenth century, through large-scale land investments and beef export (Edelman 1998). It has also been a well-known destination for short-term tourism for some decades; but particularly since 2002 residential tourism and the real estate market have undergone rapid growth. Between 2008 and 2011, I visited the area three times for several types of data collection: interviews with various population groups, a survey among residential tourists, participant observation, and analysis of secondary data sources. ${ }^{3}$

\section{Guanacaste's historical 'land grabs' and connections to North America}

In pre-colonial times, Guanacaste hosted an important and flourishing Chorotega civilisation. After the Spanish conquest, the indigenous population disappeared almost completely, and with this decimation of the population the area became marginalised for a long time (Edelman 1998). In the late nineteenth century, Guanacaste became linked to the North American

\footnotetext{
${ }^{3}$ See Van Noorloos (2012) for a detailed methodology.
} 
economy (van Noorloos 2011a), when the province saw transnational land acquisitions for cattle farming and the introduction of private property rights (Edelman 1998).

From the late nineteenth century until the early twentieth century, the livestock industry in Guanacaste experienced growth. The result was increased demand for land, which led to the strengthening of the private individual property rights of the livestock estates through judicial innovations (land titling) and other developments (fencing and forced removal of peasants) (ibid.). In northern and eastern Guanacaste, the state very regularly gave land in 'concession' to private parties, and these concessions in fact granted private property titles; in practice, land was often given away by the state at very low prices (ibid.). In the Nicoya Peninsula and research area, the church's and church brotherhoods' properties were privatised and sold during the nineteenth century; local peasants who had occupied the land were displaced in various cases, but many other peasants were able to obtain private property rights on these former church properties through the concept of squatters' rights, which were included in Costa Rica's laws in 1885 and 1888. During this period, a small number of people were able to acquire enormous amounts of land in Guanacaste. Although the livestock industry was more extensive in the interior part of the province, the hacendados regularly invaded coastal areas (ibid. 88). Already by that time there were connections to North America: since the 1880 s, there had been trade in wood from Guanacaste to North America, and a few of the large livestock estates were owned by US citizens (ibid.). As such, a corridor between North America and Guanacaste was in place (van Noorloos 2011a). This initial 'land grab' in Guanacaste was closely interrelated with the strengthening of private property rights and led to the displacement of local peasants.

In the 1950s, the North America-Guanacaste corridor was strengthened: Costa Rica began to export Guanacastean beef to the US. From about the 1950s to the 1980s, the livestock sector grew larger and more successful. The sector was dominated by large landowners (Edelman 1998), and commercialisation was led by large-scale companies, both foreign and domestic (Ramírez Cover 2008). Cattle farming was one of the main reasons for the massive deforestation of Guanacaste's forests in the early and mid-twentieth century (Calvo-Alvarado et al. 2009). At the same time, agro-industrial rice and sugarcane production took place in the province, dominated by large companies owned by national elites and greatly aided by the government through subsidies, price interventions, irrigation investments, etc. (Programa Estado de la Nación 2000; Ramírez Cover 2008).

A new 'land grab' had thus started. In the 1960s and 1970s, US citizens invested large amounts of money in land in Guanacaste for the production of rice and cotton, often together 
with Costa Rican elites. The huge sums of money that these foreign investors were prepared to spend on land infected the local real estate market with a speculative spirit, causing many local smallholders to sell their land. On the other hand, the existence of many large absentee and often foreign landowners was one of the reasons why precarismo (squatting) by peasants was still quite common - and often successful - in Guanacaste from the 1950s to the 1980s. (Edelman 1998)

In the 1980s, after having benefited from a flourishing cattle farming industry for several decades, the province's economy went into depression, and policymakers and inhabitants alike embraced tourism as an alternative development strategy for the marginalised area. The government was quick to recognise the country's potential for attracting tourism and foreign retirees: incentives included the 1964 pensionado law, which offered advantages to foreign retirees settling in Costa Rica, such as tax breaks for importing cars and household goods. In Guanacaste, retirees were not so common, although international tourism began to grow in the 1970s. The government began investing in tourism infrastructure in the 1970s, as Guanacaste's coast had been identified as one of the main tourism attractions of Central America (Morales and Pratt 2010). In 1978, Costa Rica's first government-planned tourism resort was established in Guanacaste: the Papagayo Gulf Tourism Pole (Polo Turístico Golfo de Papagayo [PTGP]) (Salas Roiz 2010). However, the effects of these investments were felt only later. Despite government measures, tourism development in Guanacaste stagnated in the 1980 s, just as it did in other sectors. However, land speculation continued, and on the coast foreign investors began to buy large properties (van Noorloos 2011a). Hence, the process of large-scale land acquisition, strengthening of private property rights, and North American investment continued, but this time speculation focused on the tourism and real estate sector.

Costa Rica underwent impressive tourism development in the 1990s, and Guanacaste particularly benefited from this boom. While some agricultural activities grew, in general the primary sector was stagnant in the area, and tourism became a very important alternative source of employment (Programa Estado de la Nación 2000; Fürst and Ruiz 2002; CEPAL 2007). The 1990s marked Guanacaste's transition towards a service economy. Investments in land throughout the coastal areas were now being developed into tourism projects and urbanisations; and in newly discovered areas, land speculation continued. A small number of 'pioneering' North Americans were already living in the area, but residential tourism was still small.

By the 2000s, tourism had become Costa Rica's second-largest source of foreign exchange earnings, only after goods export (Programa Estado de la Nación, 2007). The 2 million 
visitors threshold was reached in 2008. Guanacaste plays an important role: hotel accommodation has increased greatly in the province, particularly luxury 4- and 5-star hotels. By 2002, the rapid coming together of an extended airport, increased international charter flights from North America, and a number of high-end hotels and gated communities triggered the residential tourism boom (Janoschka 2009; Morales and Pratt 2010). As a result, a few large residential projects were further developed, and a wide range of new real estate projects were launched. Guanacaste was on its way to becoming a large-scale residential tourism destination, when in 2008 the global economic crisis hit the area and led to the cancellation of many projects and to a large oversupply of property. By 2013, a slow recovery is taking place, and new projects have been announced.

In summary, Guanacaste has undergone a number of boom-bust cycles since the first 'land grab' in the late nineteenth century. Dependency on the North American market has deepened with each cycle. Most land was in private ownership — highly concentrated in a few handsfrom early on, offering an easy base for real estate and tourism investors.

\section{The current hype: residential tourism development in Guanacaste}

The residential tourism sector in the research area (the coastal area between Papagayo and Pinilla) comprised 8 large projects and 136 smaller ones, with a total of 7,587 entities (apartments, houses, plots) in 2011. However, during the 'hype' of residential tourism investment in the period 2005-2008, much higher numbers were mentioned; many of the projects that were announced have never actually materialised or have reduced their ambitions since the crisis. Indeed, an additional 11,900 entities were announced or planned, but never completed (see Figure 5.1 for a visual depiction of planned and completed projects). Besides the media and researchers, particularly the developers and real estate agents themselves were responsible for these exaggerations of residential tourism growth figures. Despite these exaggerations, growth has clearly been rapid between 2002 and 2008, and the landscape has changed profoundly as a result. The physical landscape of residential tourism in Guanacaste is made up of various types of projects: land plot subdivisions (urbanisations), in which plots are sold without the provision of many additional services; complete villa and apartment complexes; mixed projects; and all-inclusive luxury gated communities, which combine residential elements with large international hotels and services such as golf courses and marinas. As such, residential tourism and short-term tourism are often intertwined, also 
because most apartments and houses are rented out to short-term tourists for most of the year. Many projects in Guanacaste are gated communities.

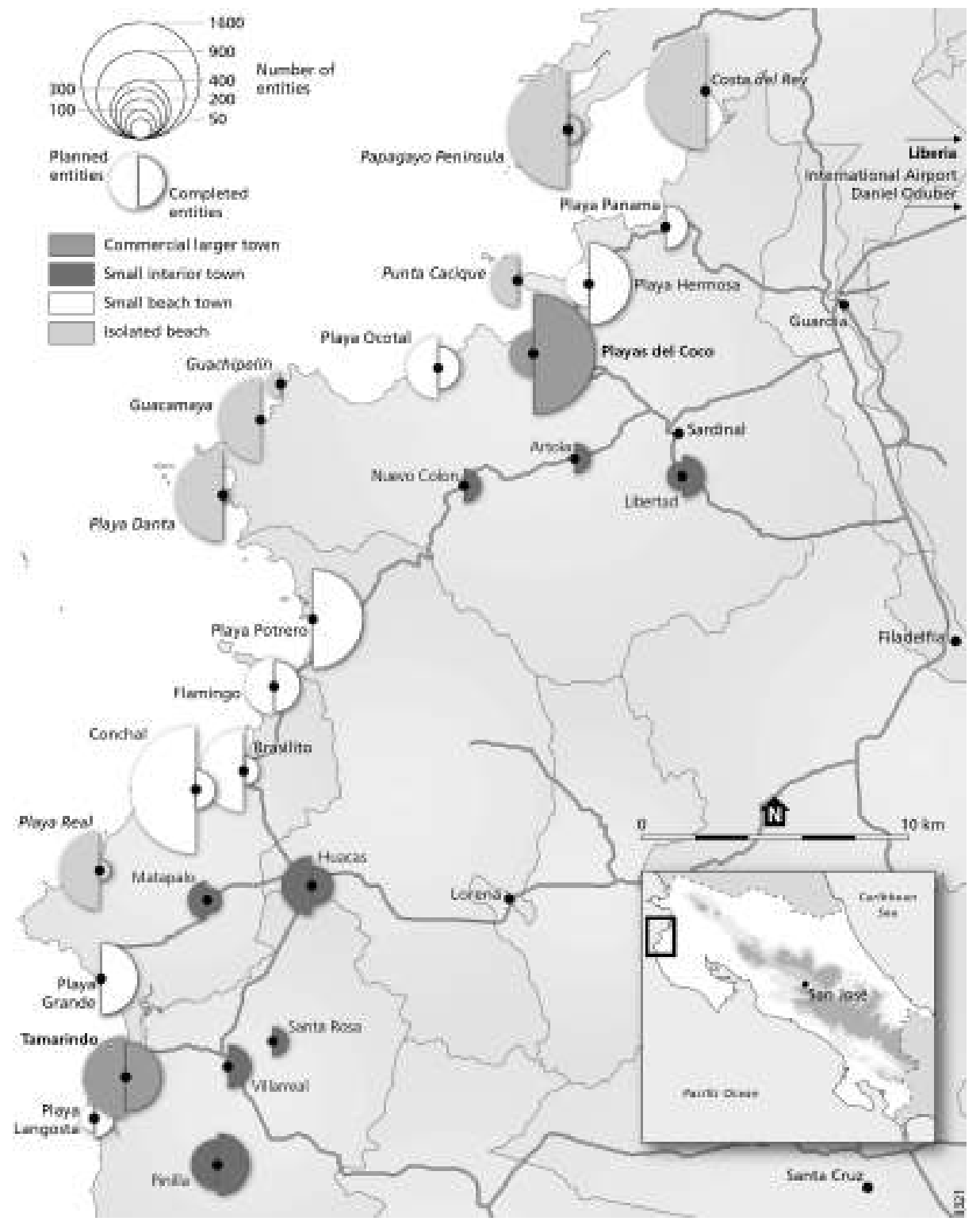

Figure 5.1. Planned/announced and completed residential tourism entities (plots, houses and apartments) per type of town, research area (2011). Source: author's research

The developers and investment capital mainly come from the US and Canada (two-thirds of the projects are partly or completely financed by North American capital), although there is also much domestic investment: 40 per cent of the projects are either completely or partly financed by Costa Rican investors. Collaborations between North American and Costa Rican investors are common. As such, a 'foreignisation' of land has clearly taken place, although the Costa Rica case illustrates that the recent focus of the 'land grab' debate on domestic 
investors and their roles as gatekeepers is also justified (see also Hilhorst, Nelen and Traoré 2011; Cotula 2012).

According to my estimates, the research area is home to about 2,000 permanent residential tourists, who make up 5 per cent of the total population. There are also $3,400-4,800$ temporary residential tourists at any given moment, accounting for 8.6-12.2 per cent of the total population. The residential tourists are mainly from the US and Canada, although some come from Europe, South America, and Costa Rica (mostly from the country's Great Metropolitan Area - the 'GAM'). Almost half are members of nuclear households without children, while slightly less than a quarter are members of nuclear households with children. The remainder are singles living alone and friends or other relatives living together.

Residential tourism in Guanacaste has both increased in quantity and diversified in terms of the characteristics of residential tourists. This development will probably continue: more and more developers may tap into the potential market of middle-class segments and Costa Rican second-home buyers, rather than just elite groups. However, there is not much space left on the Guanacaste coast for buying property individually outside of a project, and more adventurous residential tourists are finding the area too overdeveloped for buying property. It is therefore expected that residential tourism will expand to the remaining empty beaches and towards the interior of the province. The number of apartment complexes on the coast is also expected to increase.

\section{Externally led economic development}

Since its first connections to the North American economy in the late nineteenth century, Guanacaste has undergone various boom and bust cycles; each bust deepened the province's dependency on the North American market. The residential tourism industry has created specific types of new dependencies.

A number of structural factors originating in 'the West' (in this case, the US and Canada) are important for explaining the growth in, and potential for, retirement migration and for residential tourism more broadly (van Noorloos 2011a): demographic factors in North America, ${ }^{4}$ increasing health costs and decreasing retirement pensions in the US, ${ }^{5}$ cheap

\footnotetext{
${ }^{4}$ By 2030 the US population over age 65 will make up almost 71.5 million, meaning an increase of almost $80 \%$ from 2010 (US Census Bureau projections).

${ }^{5}$ A Gallup Poll in 2011 found that 53\% of US non-retired inhabitants do not think they will have enough money to live comfortably in retirement (Gallup 2011).
} 
interest rates and ease of receiving mortgages in the US (before the financial crisis), and the fact that current generations retiring in the near future have become used to international travel. General factors related to increased time-space compression are also of undeniable influence (ibid.), such as cheap and rapid travel, and improved and cheaper long-distance communication possibilities (MPI 2006; McWatters 2009). These structural factors are also interrelated with sociological changes in Western societies, where increasing numbers of people aim for a change of urban high-stress lifestyles ('the rat race') or aim to differentiate themselves from others by a different type of lifestyle (Aledo 2008; Benson and O'Reilly 2009). Related to this, the powerful ideas of a global real estate market and 'the world as a retirement destination' have been key to imagining the possibility of foreign real estate investment and residential tourism in Costa Rica (van Noorloos 2011a).

Another important push towards residential tourism was caused by innovations in the tourism industry, which were brought into Costa Rica: investors and hotel chains, mainly from the US and Spain, introduced combinations of short-term tourism and real estate/residential products (ibid.). Real estate and tourism have developed a profitable alliance in the wake of tourism's declining profitability (Deloitte-Exeltur 2005) and search for new ways of financing projects. In addition, another increasingly popular feature imported from the US are timeshare arrangements and partial ownership; in these schemes, tourists own a vacation property for a specified period per year (fractional or interval ownership). Some authors analyse these influences more in terms of political economy and the expansion strategies of international hotel chains and tourism business from Spain and the US, which have been heading to new areas - in the Spanish case, following the declining possibilities in the Balearic Islands and the wider region, and also using opportunities offered by political deregulation and free trade regimes (Cañada 2010). A number of Spanish, US, and Canadian hotel chains have established themselves in Guanacaste, and they have played a role in putting Guanacaste on the map as a large-scale, high-end tourism destination.

In terms of economic effects, it seems logical that a formerly peripheral, isolated area will flourish economically as a result of the arrival of residential tourism. This was indeed the case in Guanacaste from about 2002 to 2008, when the region saw the rapid growth of both shortterm and residential tourism. Employment and business opportunities in tourism, construction, real estate, and the related service sectors in almost all labour market segments increased strongly during this period (INEC 2000; 2011). At the same time, the number of people working in agriculture and cattle farming continued to decrease. Diverse economic 
activities developed around the construction and real estate sectors, and the traditional tourist sector and the related services continued to grow.

The growth of residential tourism has caused a chain of economic effects that are felt not only locally but also in distant areas. New employment and business opportunities often benefit other areas or people from elsewhere, both in and outside Costa Rica. Employment created by residential tourism is divided by place of origin: Nicaraguan migrants have lowpaid jobs, such as domestic work, construction, and security, whereas North Americans and domestic urban migrants often have highly skilled jobs in real estate, project development, and management. Local Guanacastecans are in between: they are active in a variety of job types, but mainly in tourism and services (INEC household surveys and census 2011). In addition, many locally operating companies maintain strong linkages with external areas: real estate agencies in Guanacaste are often part of US chains, and the construction sector is dominated by large Costa Rican companies based in the GAM. Hence, there are various financial flows to and from distant areas, and development patterns are translocal rather than locally oriented (van Noorloos 2011a).

Compared with land acquisitions in other sectors, residential tourism thus offers better opportunities for employment; even if employment and economic linkages are often translocal in character, this is not necessarily a problem. What is more problematic is that a greater focus on residential tourism - as compared with short-term tourism-can lead to the displacement of the small-scale tourism sector, a relative increase in low-paid and vulnerable employment, and greater inequalities between groups. Indeed, a comparison of both groups' expenditure patterns shows that residential tourism might be less beneficial for local people, small-scale businesses, etc., whereas it provides profitable opportunities for real estate development and related services. Furthermore, the impact of the post-2008 global economic crisis on Guanacaste has exposed the vulnerability of the sector: the growth of residential tourism has made the region increasingly more dependent on the North American real estate market and credit opportunities. Hence, the crisis has hit hard, and economic opportunities in residential tourism and related sectors have declined sharply in Guanacaste since 2008; this is particularly true for construction and real estate. The fact that residential tourism and real estate development cause greater volatility is also shown by the poverty and unemployment statistics (INEC 1997-2011): poverty, unemployment and underemployment have increased at a much higher rate in Guanacaste than in other regions of Costa Rica since the crisis. 
One of the reasons residential tourism growth can be problematic in the long term is its focus on the sale and transfer of land, rather than on the development of broader services. Land then becomes an object of investment and speculation, deeply interrelated with the financial sector. This often entails greater risks, vulnerability to shocks, volatility, and inequality (Pike and Pollard 2010).

\section{Access to land}

We have seen that in Guanacaste most land has been in private ownership - and owned by a small group of people - since the late nineteenth century. Throughout the twentieth century, domestic and transnational land investment led to land concentration, high land prices, and displacement of local populations. However, peasants had opportunities to acquire land (e.g. through squatting). The population number has been low since colonisation, so displacement was not on a massive scale. This structure later offered an easy base for real estate and tourism investors to buy land.

The main problem with residential tourism is that it has boosted land prices up to extremely high levels. Indeed, residential tourism has caused spiralling land price inflation: in the research area, the prices of land and apartments/houses have increased on average, respectively, by 17.7 and 24.3 per cent per year (2000-2011). The current average prices per square metre of 188 US\$ (land) and 2,717 US\$ (houses) have made land and housing inaccessible to most local and poor migrant groups. Since 2008, there have been slight decreases, though not enough to offer broad accessibility. Thus, many young people are unable to form their own nuclear families, or have moved towards the interior of the province, where land is still affordable. Others rent small apartments.

Nevertheless, residential tourism has not caused large-scale displacement. Some smallscale examples of displacement can be found in the coastal zone, where local people have been affected by land conflicts, de facto privatisation, and ambiguous land rights, mainly due to the inadequate implementation of regulations (van Noorloos 2011b). Indeed, the socially and environmentally protective coastal regulations that have been put in place since the $1970 \mathrm{~s}^{6}$ have been under pressure from tourism development and have suffered from a lack of

\footnotetext{
${ }^{6}$ The law on the maritime-terrestrial zone (Law No. 6043, Ley sobre la Zona Maritimo Terrestre (ZMT), of 1977 ) establishes rules for the use and protection of the first 200 metres of coastal land: the first 50 metres are inalienable public land, and the remaining 150 metres are restricted zone-government property, where land concessions can be issued (5-20 years renewable) and construction can be allowed under strict conditions.
} 
implementation and political will in recent years (ibid.). For example, there have been serious deficiencies in the land-use planning process, which has opened the door for tourism and real estate developers to elaborate such plans (CGR 2007; Román 2009). Also, the rules stipulated in the law to guarantee the use of coastal land for the public benefit are often not adhered to, ${ }^{7}$ meaning that coastal strips of land have de facto been granted to foreign tourism companies, investors have acquired large areas of land by combining several concessions, and a real estate market for coastal land concessions has appeared (Fernández Morillo 2002; Salazar 2010). In addition, local populations who have historically occupied the coastal zone (e.g. in Ostional and Brasilito) have been claiming stronger types of land rights, such as concessions or private titles, which are often denied, thus making them vulnerable to displacement (Cabrera and Sánchez 2009; Matarrita 2009; Cañada 2011).

Land transfers do not always take place in a conflictual context: many Guanacastecans have sold their land voluntarily, though often under some form of pressure (van Noorloos 2011b). The sale of land has been deeply intertwined with the change from a largely subsistence-based coastal economy based on agriculture and fishery towards a service economy based on tourism; and the lack of agrarian and subsistence-based options in a time when traditional state support for these activities has greatly declined (Edelman 2005) has prompted land sale in coastal areas (van Noorloos 2011b). Squatting is now less common and less socially accepted, although laws are still quite protective in granting rights to squatters.

Taking a historical perspective has made it clear that displacement and land concentration have mainly taken place during earlier 'land grabs'. The present pressure on land is not causing massive displacement, because of the low population numbers, low agricultural use of land, fragmentation, and spatial characteristics of investment. Residential tourism has fragmented land ownership rather than contributed to concentration, since tourism and real estate investors have acquired former cattle haciendas and subdivided them. Also, they have acquired land on isolated, often uninhabited beaches, because of the tourist quality of such areas. The land market in Guanacaste is highly fragmented: it consists of many segments with different price ranges and characteristics. As such, local populations are still living in the area alongside new richer groups.

Concessions cannot be granted to foreigners who have lived for less than 5 years in Costa Rica, or to companies with more than half of their capital derived from foreign sources.

${ }^{7}$ This is related to gaps in the law (e.g. the possibility of establishing Sociedades Anónimas or 'corporations', whereby foreign capital and multiple concessions held by the same person can be hidden), but it is also a result of the lack of adequate control by municipalities and ICT - and in some cases, the involvement of powerful political figures (Salazar 2010). 


\section{Policy and community involvement}

While the first 'land grabs' in Guanacaste took place in a context of state absence, the 1950s marked the entrance of a strong and social Costa Rican state and a state modernisation project that extended far into the provinces. Not only did the central government establish large-scale projects in Guanacaste (e.g. large hydroelectric and irrigation projects), it also established many schools and health clinics (Programa Estado de la Nación 2000; Ramírez Cover 2008); hence, people benefited from relatively well-established institutions. Nevertheless, the debt crisis of the late-1970s-1980s and the subsequent neoliberal policies marked the beginning of a new era. The sidelining of smallholder peasant production has characterised Guanacaste since the 1980s (Edelman 2005), and the lack of viable alternatives for smallholders plays a role in current land and economic conversion. At the same time, state policies focused on attracting FDI not only in large-scale, non-traditional agriculture but also in new tourism and services sectors. ${ }^{8}$ In the 1990 s and 2000 s, whereas institutions were still relatively strong, it was increasingly difficult to counterbalance the forces of FDI-driven land conversion, environmental and social change, and neoliberal tendencies in Costa Rica's government, which had been set in pace in previous decades.

This contrast between Costa Rica's relatively strong and protective state institutions and laws (e.g. an exceptionally strong environmental legal framework) on the one hand, and the unregulated private-led development in Guanacaste's coast on the other, is one of the main paradoxes. Government implementation and control of environmental and spatial regulations has been largely deficient (Janoschka 2009; Barrantes-Reynolds 2010; CGR 2009, in Programa Estado de la Nación 2010). National institutions and particularly local governments largely lack the necessary human and financial capacities and internal coordination-and often also the political will. This has led to the chaotic and unplanned proliferation of residential tourism in Guanacaste, with a range of socio-environmental issues - for example, water exploitation and privatisation, endangered conservation policies, and coastal zone privatisation — and protests. Hence, strict national regulations and laws and elaborate checks

\footnotetext{
${ }^{8}$ The Costa Rican government has created advantageous conditions for investment in large-scale tourism and real estate development in various ways, such as through infrastructure and direct involvement in investment deals (van Noorloos 2011a and 2011b).
} 
and balances cannot always prevent damage in the face of rapid developments, important economic and political interests, and local government's traditional weakness.

With a central government that lacks a coherent policy, and with weak local governments and a private sector that cannot be expected to offer all the solutions, citizens and civil society have an important role to play in improving the implementation and control of regulations, and in achieving positive change. Indeed, communities and civil society are often assigned a key role in mitigating effects of large-scale land acquisitions, through participation in decision-making on land deals and compensation, protecting local land rights, and improving transparency (Global Witness 2012). Some successful protests in the interior of Guanacaste against the exploitation of local aquifers for tourism and residential projects on the coast have shown that local action can indeed be effective: they managed to slow down or halt residential tourism growth (see also Van Eeghen 2011). However, the power of communities and civil society to influence local affairs is still largely insufficient: central government and the private sector are increasingly recentralising and privatising the control of natural resources; the influence of NGOs and local groups is mainly ex post and not preventive; and the connection between these groups and local government is still weak. In addition, the fragmentation and diversity of the population makes it difficult to achieve democratic participation in decisionmaking. Indeed, residential tourism has transformed Guanacaste into a transnational space (Torres and Momsen 2005), which hosts many groups that have different origins and different goals and interests, groups comprising local people, residential tourists, and labour migrants (the latter mostly from Nicaragua and the GAM). The high level of fragmentation, mobility, temporariness, and absenteeism in Guanacaste-combined with the presence of many

migrants who do not envision a future in the area-circumscribes successful community organising (van Noorloos forthcoming).

\section{Conclusion}

This chapter has shown that the focus of the 'land grab' debate should not be limited to direct displacement but should also include long-term effects and broader processes of exclusion. The analysis of historical on-going land acquisitions for different purposes in a specific area offers a unique opportunity to understand the long-term effects of 'land grabs' and the formation of 'corridors'. 
The northwest coast of Costa Rica has been subject to land grabs ever since colonisation, but particularly since the late-nineteenth century, when a small number of foreign and domestic investors were able to acquire huge amounts of land, mainly for the cattle sector. Since its first connections to the North American economy in the late-nineteenth century, Guanacaste has undergone various boom and bust cycles, and each bust deepened the province's dependency on the North American market, through beef export, investment in land for cattle farms, speculation, etc. Most land was in private ownership-highly concentrated in a few hands - from early on. Throughout the twentieth century, large-scale investment in land led to land concentration, high land prices, and displacement of local populations. However, peasants had opportunities to acquire land-for example, through protective institutions for coastal land and squatting. The population number has been low since colonisation, so displacement was not on a massive scale.

This structure later offered an easy base for real estate and tourism investors to buy land, thereby continuing externally led development and consolidating the North AmericaGuanacaste corridor (van Noorloos 2011a). Since displacement and land concentration mainly took place during earlier 'land grabs', with the low population number the present pressure on land is not causing massive displacement. Residential tourism has fragmented land ownership rather than contributed to concentration; it causes a process of gentrification and foreignisation, rather than a land grab as such. Nevertheless, there are many problems: while residential tourism receives little attention in the land grab debate, this chapter has shown that it puts great pressure on local land markets. It endangers access to land for local and poor migrant groups, as land is increasingly becoming an object of speculation rather than production. These processes take place in a broader context: the sidelining of smallholder peasant production has characterised Guanacaste since the 1980s (Edelman 2005), and the lack of viable alternatives for smallholders plays a role in current land and economic conversion.

Compared with land acquisitions in other sectors, residential tourism offers better opportunities for employment; but, as in other sectors, much of the work is vulnerable, low in quality, and often performed my migrants; and real estate-led development is vulnerable and volatile. The residential tourism industry has thus created new opportunities, but also specific types of new dependencies. Costa Rica's strict national regulations and laws and elaborate checks and balances often fail to prevent damage in the face of rapid developments, important economic and political interests, and local government's traditional weakness. 
The case of residential tourism can teach us some important lessons for the debate on global land acquisitions. First, the overall development effects of land investments can be understood only by exploring the articulations between ecological, economic, and social strands of sustainable development. For example, in the tourist industry, economic and environmental aspects are interwoven in complex ways. Second, the impact of residential tourism is not limited to the local or regional level: distant regions are also directly affected through flows of capital, goods, people, etc. By taking into account these translocal flows, corridors, and effects, we can arrive at a broader understanding, which cannot be provided by static, bounded, impact evaluations (Zoomers and van Westen 2011). Third, discussions on land issues often emphasise certain types of regulation and governance, such as voluntary regulations for responsible investment and strengthening national counterbalancing institutions. However, these measures may lack effectiveness if broader underlying developments are left untouched (Borras and Franco 2010; Zoomers 2013). This research has also shown that while involving the local population in, for example, decision-making on land or compensation mechanisms is important, it is an extremely complex process.

Finally, a temporal and historical dimension should be integrated in evaluations of land investment and sustainable development (Seghezzo 2009): it is important to provide a dynamic perspective, whereas long-term effects are often not sufficiently taken into account. The case of Guanacaste shows that transnational land investment and external dependencies can be deeply rooted in a region's history. This makes current processes more difficult to regulate or counter, while at the same time, these historical factors also influence the way in which current land acquisitions are affecting the region. In Guanacaste it is clear that 'land grabs' can set in pace a process of land-based capitalism and land concentration that is very difficult to counter at later stages: whereas economic activities have changed, external control over land is on-going.

\section{References}

Aledo, A. (2008) 'De la tierra al suelo: la transformación del paisaje y el Nuevo Turismo Residencial', ARBOR Ciencia, Pensamiento y Cultura 729: 99-113. 
Anseeuw, W., L. Alden Wily, L. Cotula and M. Taylor (2012) Land Rights and the Rush for Land: Findings of the Global Commercial Pressures on Land Research Project, Rome: International Land Coalition.

Barrantes-Reynolds, M.P. (2010) “"Costa Rica -no artificial ingredients”: the "green” state's challenge in the management of the residential tourism sector in the coastal area'. Unpublished MPhil thesis, St Antony's College, University of Oxford.

Benson, M. and O'Reilly, K. (2009) 'Migration and the search for a better way of life: a critical exploration of lifestyle migration', The Sociological Review 57(4): 608-625.

Borras, S. and Franco, J. (2010) Towards a broader view of the politics of global land grab: rethinking land issues, reframing resistance, Working paper, ICAS Review Paper Series No. 1.

Borras, S.M., J.C. Franco, S. Gómez, C. Kay and M. Spoor (2012) 'Land Grabbing in Latin America and the Caribbean', Journal of Peasant Studies 39(3-4): 845-872.

Cabrera, J. and S. Sánchez (2009) Marco Legal y Estructura Institucional del Desarrollo Turístico e Inmobiliario en la Costa Pacífica de Costa Rica. Report for Center for Responsible Travel, The Impact of Tourism Related Development along Costa Rica's Pacific coast, Washington, DC / Stanford, CA: Center for Responsible Travel.

Calvo-Alvarado, J., B. McLennan, A. Sánchez-Azofeifa and T. Garvin (2009) 'Deforestation and forest restoration in Guanacaste, Costa Rica: Putting conservation policies in context', Forest Ecology and Management 258: 931-940.

Cañada, E. (2010) Turismo en Centroamérica: Nuevo escenario de conflicto social. Report for Informes en Contraste_-Programa Turismo Responsable 1 (April 2010), Barcelona: Alba Sud.

Cañada, E. (2011) Costa Rica: Comunidades costeras en lucha. Entrevista a Wilmar Matarrita, Alba Sud-Opiniones en Desarrollo 12, June 2011. 
CEPAL (Comisión Económica para América Latina y el Caribe-UN) (2007) Turismo y condiciones sociales en Centroamérica: Las experiencias en Costa Rica y Nicaragua, Santiago, Chile: CEPAL.

CGR (Contraloría General de la República de Costa Rica) (2007) Memoria Anual 2007, San José, Costa Rica: CGR.

Cotula, L. (2012) 'The International Political Economy of the Global Land Rush. A critical appraisal of trends, scale, geography and drivers', Journal of Peasant Studies 39(3-4): 649680 .

Deloitte-Exeltur (Alianza para la Excelencia Turística) (2005) Impactos sobre el entorno, la economía y el empleo de los distintos modelos de desarrollo turístico del litoral Mediterráneo Español, Baleares y Canarias-Resumen Ejecutivo, Madrid: Exeltur.

Edelman, M. (1998) La lógica del latifundio. Las grandes propiedades del noroeste de Costa Rica desde fines del siglo XIX. (Translation of 1992 'The logic of the latifundio: the large estates of northwestern Costa Rica since the late nineteenth century'), San José, Costa Rica: Editorial de la Universidad de Costa Rica.

Edelman, M. (2005) Campesinos contra la globalización. Movimientos sociales rurales en Costa Rica (Translation of 1999 'Peasants Against Globalization: Rural Social Movements in Costa Rica'), San José, Costa Rica: Editorial de la Universidad de Costa Rica.

Fairhead, J., M. Leach and I. Scoones (2012) 'Green Grabbing. A new appropriation of nature?', Journal of Peasant Studies 39(2): 237-261.

Fernández Morillo, M.T. (2002) 'Dinámica de uso y tenencia de la tierra en la zona marítimo terrestre de dos áreas del Pacífico de Costa Rica', in: E. Fürst and W. Hein (eds) Turismo de larga distancia y desarrollo regional en Costa Rica, San Jose, Costa Rica: DEI (Asociación Departamento Ecumenico de Investigaciones), pp. 347-374.

Fürst, E. and K. Ruiz (2002) 'Turismo y empleo en Costa Rica: caracteristicas nacionales y 
tendencies de desarrollo reciente', in: E. Fürst and W. Hein (eds) Turismo de larga distancia y desarrollo regional en Costa Rica, San Jose, Costa Rica: DEI (Asociación Departamento Ecumenico de Investigaciones), pp.115-144.

Gallup (2011) In U.S., 53\% Worry About Having Enough Money in Retirement, Article (25 April 2011).

German, L., G. Schoneveld and E. Mwangi (2011) Contemporary Processes of Large-Scale Land Acquisition by Investors. Case Studies from sub-Saharan Africa. Cifor Occasional Paper 68.

Global Witness (2012) Dealing with Disclosure.Iimproving transparency in decision-making over large-scale land acquisitions, allocations and investments, London: Global Witness / Oakland Institute / International Land Coalition.

Gustafson, P. (2008) 'Transnationalism in Retirement Migration. The case of North European retirees in Spain', Ethnic and Racial Studies 31(3): 451-475.

Hilhorst, T., J. Nelen and N. Traoré (2011) Agrarian change below the radar screen: Rising farmland acquisitions by domestic investors in West Africa. Results from a survey in Benin, Burkina Faso and Niger, LANDac short-term research paper.

Hoogendoorn, G. and G. Visser (2010) 'The Role of Second Homes in Local Economic Development in Five Small South African Towns', Development Southern Africa 27(4): 547562 .

INEC (Instituto Nacional de Estadísticas y Censos Costa Rica) (2000). Census 2000.

INEC (Instituto Nacional de Estadísticas y Censos Costa Rica) (2011). Census 2011.

INEC (Instituto Nacional de Estadísticas y Censos Costa Rica) (1997-2011). Household Surveys. 
Janoschka, M. (2009) 'The Contested Spaces of Lifestyle Mobilities. Regime analysis as a tool to study political claims in Latin American retirement destinations', Die Erde 14: 251274.

Matarrita, W. (2009) 'Comunicado del Frente Nacional de Comunidades Amenazadas por Políticas de Extinción', El Pregón, 8 May 2009.

McIntyre, N. (2009) 'Rethinking Amenity Migration. Integrating mobility, lifestyle and social-ecological systems', Die Erde 140(3): 229-250.

McWatters, M.R. (2009) Residential Tourism. (De)constructing paradise, Bristol: Channel View.

Morales, L. and L. Pratt (2010) Analysis of the Daniel Oduber Quirós International Airport, Liberia, Guanacaste. Report for Center for Responsible Travel, The Impact of Tourism Related Development along Costa Rica's Pacific coast, Washington, DC / Stanford, CA: Center for Responsible Travel.

MPI (Migration Policy Institute) (2006) America's Emigrants. US retirement migration to Mexico and Panama, Washington: MPI.

Oxfam (2011) Land and Power. The growing scandal surrounding the new wave of investments in land, Oxford: Oxfam.

Peluso, N. and C. Lund (2011) 'New Frontiers of Land Control: Introduction', Journal of Peasant Studies 38(4): 667-681.

Pike, A. and J. Pollard (2010) ‘Economic Geographies of Financialization’, Economic Geography 86(1): 29-51.

Programa Estado de la Nación (2000) 'Capítulo 6. Los desafíos de la Región Chorotega', in: Programa Estado de la Nación, Informe Estado de la Nación en desarrollo humano sostenible 6, San José, Costa Rica: Programa Estado de la Nación, pp. 307-360. 
Programa Estado de la Nación (2007) 'Aporte especial: Diversidad de destinos y desafíos del turismo en Costa Rica: los casos de Tamarindo y La Fortuna', in: Programa Estado de la Nación, Informe Estado de la Nación en desarrollo humano sostenible 13, San José, Costa Rica: Programa Estado de la Nación, pp.193-224.

Programa Estado de la Nación (2010) Informe Estado de la Nación en desarrollo humano sostenible 16, San José, Costa Rica: Programa Estado de la Nación.

Ramírez Cover, A. (2008) 'Conflictos socioambientales y recursos hídricos en Guanacaste; una descripción desde el cambio en el estilo de desarrollo (1997-2006)', Anuario de Estudios Centroamericanos 33-3: 359-385.

RevealEstate (2009) The 2009 Annual Central America International Real Estate PriceRank, Blog post, 16 October 2009.

Román, M. (2009) Dinámica del mercado inmobiliario en la costa pacífica de Costa Rica, Report for Center for Responsible Travel, The Impact of Tourism Related Development along Costa Rica's Pacific coast, Washington, DC / Stanford, CA: Center for Responsible Travel.

Salas Roiz, A. (2010) Polo Turístico Golfo de Papagayo, Guanacaste, Costa Rica. Análisis del Polo Turístico Golfo de Papagayo como un modelo único gubernamental de concesión turistica, Report for Center for Responsible Travel, The Impact of Tourism Related Development along Costa Rica's Pacific coast, Washington, DC / Stanford, CA: Center for Responsible Travel.

Salazar, C. (2010) 'Fiscalía Ambiental ordenó paralizar obras en proyecto turístico de Guanacaste', El País, 30 October 2010.

Seghezzo, L. (2009) 'The Five Dimensions of Sustainability', Environmental Politics 18(4): 539-556.

Torres, R.M. and J.D. Momsen (2005) 'Gringolandia: The construction of a new tourist space in Mexico', Annals of the Association of American Geographers 95: 314-335. 
Van Eeghen, S. (2011) Water conflicts in Costa Rica? Sardinal: a case study on the emergence of a water conflict in the context of high speed growth in real estate and tourism, MSc thesis, Utrecht University.

Van Noorloos, F. (2011a) 'A Transnational Networked Space: tracing residential tourism and its multi-local implications in Costa Rica', International Development Planning Review 33(4): 429-444.

Van Noorloos, F. (2011b) 'Residential Tourism Causing Land Privatization and Alienation: New Pressures on Costa Rica's Coasts', Development 54(1): 85-90.

Van Noorloos, F. (2012) Whose place in the sun? Residential tourism and its implications for equitable and sustainable development in Guanacaste, Costa Rica, $\mathrm{PhD}$ thesis University of Utrecht. Delft: Eburon.

Van Noorloos, F. (2013, forthcoming) 'Residential Tourism and Multiple Mobilities: local citizenship and community fragmentation in Costa Rica', Sustainability 5.

Williams, A.M. and C.M. Hall (2000) 'Tourism and Migration: New Relationships between Production and Consumption', Tourism Geographies 2(1): 5-27.

Zoomers, A. (2010) 'Globalisation and the Foreignisation of Space. seven processes driving the current global land grab', Journal of Peasant Studies 37(2): 429-447.

Zoomers, A. (2013) 'A Critical Review of the Policy Debate on Large Scale Land Acquisition: Fighting the Symptoms or Killing the Heart?', in: S.J.T.M. Evers, C. Seagle and F. Krijtenburg (eds) Africa for sale? Positioning the state, land and society in foreign largescale land acquisitions in Africa, Leiden, Netherlands: Brill Publishers, pp.55-78.

Zoomers, A. and G. Van Westen (2011) 'Introduction: Translocal development, development corridors and development chains', International Development Planning Review 33(4): 377388. 